\title{
CRITIQUE OF RESOURCE CURSE FRAMEWORK
}

\author{
Yunusa Hassan \\ Department of Geography, Umar Suleiman College of Education Gashua, Nigeria \\ Department of Geography, NIMS University Rajasthan, India \\ Email: contactyunusah@gmail.com
}

\begin{abstract}
It is a common axiom that most resource rich countries are thought to be having greater tendency of contracting natural resource effects. Being a resource rich country has pressed many developing economies to over-spend on recurrent expenditure, wasteful spending on provision of subsidies, palliatives, social relief packages as well as construction of monuments ignoring the essential sector of the economy and welfare; such as healthcare services, infrastructures, education, industries, etc. This discourse is a review of critically underpinning framework of natural resource curse effects through identifying key driving mechanisms. This study uncovered that these key mechanisms are classified into the economic mechanism on one part and the political mechanism on the other part. The economic mechanisms were thought to be closely associated with regional economic realities and their momentous poor fiscal performance, whereas the political mechanisms were believed to be confined to political complexities of the natural resource regions and institutions. However, the study further identified a recent consensus on recent political variables on linkages between regional natural resource wealth and development outcomes and also emphasized on comprehensive indulgence of varieties of social feasibility issues. Moreover, this discourse further affirmed the essential need for more studies at country considering the close affiliation of resource curse rents and the decision of political elites and ruling class.
\end{abstract}

Key words: Dutch Disease, Geographical Political Economy, Resource Dependence

\section{Introduction}

Natural resource curse is a system of political economy that believed countries endowed with natural resources have been found to be lacking relative to countries with fewer natural resources in most of developmental and prosperity indices (Auty 1993; Arezki and Brückner, 2011). This political economic thought is also known as the "paradox of plenty". It is a common axiom that there are various inter-related factors that are affecting how natural resource wealth (rent) consequently resulted to effective economic growth or otherwise. Though, there is connecting as well as various divergences and conflicting ideas regarding the natural resource curse issues in several studies at both national and global arena, however, there is no universally one size fit all accepted concept on how natural resource rent generated can be spend. Most resource-rich countries of the world have proven to be hopelessness in term of achieving effective natural resource rent utilization despites their abundances (Auty, 1993; Gylfason, 1999; Sarmidi, 2014).

There is no model that provided universal acceptability with proven records of curing effects of natural resource curse. Therefore, this study attempts to theoretically provide succinct dossier on the effects of resource curse on various regions' economies and development. Many studies have demonstrated that the effects of natural resource abundances in most resource-rich countries is usually less economically viable, consequently, economies endowed with abundance resources mostly ends up expose to 
conflicts and authoritarian regime relative to economies without resources (Humphreys et al., 2007; Ross, 2007). Though, it was on several occasions proven that when resource rents are efficiently utilized, they tend to be potentially capable of creating greater regional prosperity, growths and developments (Auty 1993; Gylfason, 1999; Humphreys et al., 2007; Sarmidi, 2014). And on a contrary note, when natural resource rents are squandered and mismanaged, they likewise tend to exposes the resource region to social conflicts, prone to corruption and unrest that may largely be associated with economic instability and lifelong environmental damages caused (Auty, 1993; Ross, 2007).

Since most of non-renewable resources and some fraction of renewable resources only exist in an exhaustible quantity, this means that they are available in limited quantity and can be used up if not properly managed (Badeeb et al., 2016). That is why reasonable studies of recent natural resource economics and theories prioritize the identification of diverse measures such as optimum resource exploitation for realization of economic benefits. Badeeb et al. (2016) also reported optimum resource exploitation is essentially desirable in order to prevent faster depletion and extinction. However, the recent rapid exploitation of natural resource was driven by rapid population increase and increasing standard of living (Sarmidi, 2014; Farhadi et al., 2015). Moreover, on a temporal scale of most renewable resources exploitations, the exhaustion periods are mainly greater than the resource recovery period; therefore, it creates the setting of simple scarcity. For example, the rate at which carbon di oxide $\left(\mathrm{CO}_{2}\right)$ is primarily recycled through photosynthesis, however, the rate at which recycle is done is greater than the rate at which $\mathrm{CO}_{2}$ is realized in the atmosphere (Frankel, 2010). Another example is the rate at which crude oil was recycled usually has an average duration of millions of years; hence, it recent exploitation rate is far greater than it regeneration duration (Frankel, 2010).

\section{Causes of Natural Resource Curse}

Several social scientists and economists have identified various causal channels of resources curse, and also anticipated different results in economic prosperity and development. Many studies have demonstrated that most of these resource-rich nations have greater tendencies of over-spending on wasteful monuments (Humphreys et al., 2007 and Ross, 2007). For example, these countries spent more fuel subsidies and large monuments while under-spending on major sections of the economy and welfare; for instance, the health care services, infrastructures, education, etc. (Auty 1993; Arezki and Brückner, 2011; Sarmidi, 2014). Though, this anticipation have some defects: such as the possibility of deliberate or accidental bias on the perceived influences of resource dependency as well as the impacts of institutional environment (Lam and Wantchekon, 2003; Sarmidi, 2014; Gylfason, 1999; Isham, 2005; Brunnschweiler, 2008; Blanco and Grier, 2012; Bhattacharyya and Hodler, 2014). However, the second defect can be influenced by the relative level of democratic influences on the resource measures though various effects of the discovery of oil on the respected region' estimated endowment (Arezki and Nabli, 2012).

This study identified various studies that demonstrated the domination of resource effects on particular institutional aspects and policies; for instance, a study by Beck and Laeven (2006) on the discovery of Eastern Europe resources which consequently associated the delayed the region' reforms in the region the resource discovery. It is demonstrated that resource rents mostly expose countries to possible autocratic administration, buying supports and riggings of elections. Moreover, another study also reported that the lesser the amount of media freedom in oil-rich nations, the higher the chances of autocratic regimes (Egorov et al., 2009). A study conducted by Andersen and Aslaksen (2013) further uncovered that natural resource rent only affects leadership duration and bonding to non-democratic regimes. Even though several studies had empirically proved and that in most dreadful regional institutions, natural resources rent thus increases corruption and consequently reduces corporate transparency (Bhattacharyya and Hodler, 2010; Vincente, 2010; Andersen and Aslaksen, 2013). 
A natural resource rent especially in weaker institutional settings was believed to be delaying the diversification and reforms within the economy and also increases incentives that engaged in various forms of rent-seeking. In an autocratic setting of natural resource rents, national wealth is mainly used by the elites to strengthen their hands to hold on firmly to power (Bhattacharyya and Hodler, 2010). Moreover, this study further identified many successful examples of efficient management of natural resource rents; for instance, regional establishment of sovereign wealth funds that are capable of reducing price volatility and subsequent creation of decorum for transparency that can be easily implantable. In line with Stevens and Dietsche (2008) study that reported that the use of large monetary investments could be perfectly legitimate, and also consumption can be skewed toward recent capital scarce developing economies. In the midst of all these uncertainties, this study recognizes the following implications of natural resource rents for overall policies and also anticipates both political as well as the economic regional mechanisms that are underpinning to the contemporary resource curse effects.

\section{Mechanisms of Natural Resource Curse}

The present study critically analyzed various studies related to the roles of natural resources curse towards regional economic growth and prosperity, and consequently discovered that social scientists and economists have in various time analyzes this notion and successfully identified numerous mechanisms. Some of the studies that have empirically provided detailed literatures on the contemporary resource curse adversities include Leiti and Weidmann (1999), Ross (2007), Frankel (2010), Arezki and Nabili (2012), Boschini et al. (2013), Apergis and Payne, (2014), Bhattacharyya and Hodler (2014), and Badeeb et al., (2016). These above mentioned studies had reported about the leading theories and concepts on how these special characteristics of natural resource revenue adversely create several challenges for resource-rich economies. Therefore, the present study further categorized the mechanisms of natural resource curse into two overlapping groups, i.e. economic and political mechanism.

\section{Economic Mechanism}

The basis of many natural resource based trails on development and retardation on long run are traced to diverse allied economic mechanism; such as the Dutch diseases, failure of economic policies, volatility of price, the neglect of the education, inefficient spending and borrowing.

\section{Dutch Diseases}

Dutch diseases model was initially developed by Corden and Neary (1982) and Corden (1984) as result of the Dutch manufacturing sector loosen after the discovery of natural gas. A well-known explanation of this model suggested that a resource windfall generates additional wealth which on the other hand raises the prices of non-tradable goods and services. This in turn leads to real exchange rate appreciation and higher wages in the services sector (Corden, 1984). The resulting reallocation of capital and labor to the nontradable sector and to the resource sector causes the manufacturing sector to contract, and was called "de-industrialization" by Sachs and Warner (1997). This form of deindustrialization mechanism is called the Dutch diseases. Dutch disease is a concept of geographical political economy that occurred due to the exchange rate appreciation and the depreciation of manufacturing exports which was first observed in Netherlands following the discovery of North Sea gas in late 1950s (Sachs and Warner, 2001). The Dutch diseases mechanism demonstrated that any frenziedly immense raise in natural resource revenue can subsequently hurts other sectors of the economy (particularly export-based manufacturing sector).

A study by Frankel (2010) reported that the negative effects of resource rent on the resource-rich nation's economic growth, hence, this study categorically refer to this notion as "spending effect". Due to the higher pay for labor shift to the natural resource based sector, accordingly, there is an increasing cost of production of other traditionally export 
sector; for instance, agriculture and manufacturing industries (Frankel, 2010). This unfavorable scenario was found to have negatively affected the non-natural resource based sectors, and it is called the resource "pull effect" (Humphreys et al., 2007). Though, the harmful effect of natural resources on other industries is not really documented in many developing economies like Nigeria, hence, it was believed to be significantly documented in other countries such as Iran, Russia, Trinidad and Tobago, Venezuela, Angola, Ghana, Botswana, and all of which have either stunted manufacturing sectors or saw abrupt decline in manufacturing (Mehrara, 2009; Hammond, 2011; Farhadi et al., 2015; Blanco and Grier, 2012; Apergis et al., 2014). However, assorted literatures have reported that the impacts of Dutch diseases can be minimized if the affected nation has absorptive competence to transform resource rent generations into tangible investments such as the construction of roads and electricity generation (Hammond, 2011; Apergis et al., 2014; Farhadi et al., 2015;).

Recently, some countries like Norway, UAE, Chile and Indonesia have successfully managed to overcome the effects of Dutch diseases for more than over three decades (Ismail, 2010; Boschini et al., 2013). Though, these studies further empirically affirmed that there are still possibilities of numerous outcomes besides been suffering from adverse effects of Dutch diseases (Ismail, 2010; Boschini et al., 2013). But it is also believed that a resource boom has capability of causing declining any regional manufacturing exports in addition to expansion of the services sector (Sala-i-Martin and Subramanian, 2003). However, this study thought that the theory of Dutch disease failed to explain the rationale why some countries fail and others succeeded besides all living under given level of resource dependence. These explained why the contractions of the manufacturing sector is not necessarily harmful per se, but mainly lowers development on long-run regional growth and development as seen in Saudi Arabia, Gulf Emirate, Kazakhstan and Mexico.

\section{Failure of Economic Policies}

Most resource-rich economies tend to have over-confidence in their economic policies which in return resulted to lower economic productivity. A study by Ross (2007) reported that a natural resource funded economy mainly cushioned urbanization, neglecting the higher education shortfall and general infrastructures. On the demand side, this resource dependency is also competent in diminishing peoples' incentives to accumulate human capital as further reported by Ross (2007). The reflection from both sides (the demand and supply) supported the public expenditure on education relative to national income is inversely related to natural capital as proven by Beck and Leaven (2006). Hence, there is no universally generalized metrics for quantifying failure in economic policies as proven by several studies (Beck and Leaven, 2006; Ross, 2007). For instance, this study understands that Norway is conspicuous as an economic producer topped international league tables for governance and economic performance. On the other hand, the study also identified Botswana and Conga to be having abundant diamond deposits, however, Botswana is paramount in terms of stability and rapid income growth, while Congo is among the worst.

\section{Volatility in Commodity Price}

Market instability through commodity price volatility increases as uncertainty hindered efficient economic development, thereby measuring revenue from the natural resource sector become complicated. Various studies reported that price volatility lessen economic growth at every level (Humphreys et al., 2007; Frankel, 2010). This study understood that commodity price volatility mainly shrinks foreign exchange earnings and government revenues, and subsequently reduce the country's abilities to meet the condition required for expansionary monetary policy (Frankel, 2010). Though, Humphreys et al. (2007) argued that the extent of resource prices fluctuations can be amplified by international lending. However, this study understood that when commodity prices are high within any region, the commodity-rich nations borrows from abroad to worsen the boom as seen notably in many countries within Middle East, Africa and Latin America. On a contrary note, this study further believed that when the prices of commodities fall within resource rich economies, 
international lenders demand repayment as well as push for expenditure reduction. In this regards, the response and counter response pushed many resource rich nations like Nigeria, Ecuador, Indonesia, Iran, Bolivia, Venezuela and Mexico to rolled deep into debt crises in 1980s as reported by Humphreys et al. (2007).

\section{Inefficient Spending and Borrowing}

The present study understood that several literatures reported that it is easier said than done to resourcefully to spend in an incessant economy that is facing unpredicted and fluctuating revenues (Vincente, P. C. 2010; Bulte et al., 2005). Though, accumulated rents collected by resource rich governments can change drastically because of resource market price fluctuations as well as production cost. Most resource rich nations often get trapped in "boom-bust" cycles where the revenue are spent on legacy projects (such as large government buildings and airports) and later make painful spending cuts when revenue declined (Vincente, P. C. 2010). Several pertinent literatures have demonstrated that resource rich nations usually have greater tendency to over-spend on government salaries, inefficient fuel subsidies and large monuments (Singer, 1950; Bulte et al., 2005; Hammond, 2011).

In most cases, these resource rich governments often over burrowed thinking that their economies received colossal revenues. Hence, this form of behavior led to the debt crisis in countries like Nigeria, Mexico and Venezuela (Hammond, 2011). This study confirmed the thought of Loayza et al. (2013) that this scenario was believed to reason for exposure of private industries, and their subsequent over investing during the boom times as well as experiencing prevalent bankruptcy afterwards. On the other hand, United State, Australia and Norway are example of developed resource rich nations with efficient spending and limited borrowings.

\section{Political Mechanisms}

Numerous social scientists in their respective studies acknowledge some key political channels or mechanisms through which resource curse may operate politically. For instance, diverse issues such as rent seeking, corruption, weak institutional development, conflict, democracy, patriarchy and gender challenges, social and environmental problems are systematically recognized as key political mechanisms of natural resource curse (Leiti and Weidmann, 1999; Collier and Hoeffler, 2005; Arezki and Gylfason, 2011; Barma et al., 2012; Apergis and Payne, 2014; Sarmidi et al., 2014).

\section{Rent Seeking}

A study by Lam and Wantchekon (2003) labeled the rent seeking as a "Political Dutch Disease". It was argued by many studies that in some countries, the bonus of resources revenue mostly boosts only the power of political elites and leaders, and consequently believed to be having the ability to broaden revenue disparities within the resource rich regions (Gylfason, 2001; Hodler, 2006; limi, 2007; Deacon and Rode, 2012). In rent seeking, it was believed that revenues generated from natural resource rent are mainly shared by the elite groups to their immediate circles rather than investing it on upgrade of socioeconomic infrastructures. This study is in line with Davis and Tilton (2005) and limi (2007) studies which concurred that the main cause of conflict between domestic stakeholders (i.e. politicians and local tribes) is mainly the windfall of resource revenue. Moreover, the study affirmed the finding of renowned political analyst "Paul Collier" who uncovered that for any given five-year period, the chances of civil war in Africa's resource rich nations is at about 25 percent whereas for the non-resource rich nations is at about 1 percent (limi, 2007).

\section{Weaker Institutional Development}

It is discovered that most resource rich nations are having weak institution where the elites or leaders usually take large sums of cash (Deacon and Rode, 2012). Many studies backed this claim with reports that most countries with single fat point of resource rent such as oil 
and other precious mineral resources are prone to be captured by powerful group of elites (Bulte et al., 2005; Arezki and Brückner, 2011; Arezki and Nabli, 2012; Bhattacharyya and Collier, 2014). This theory accounted that key national tools or machineries such as the national companies and sovereign wealth funds are easily captured by these powerful elites and ruling class (Bhattacharyya and Collier, 2014). Consequently, in most of these resource rich countries in Africa, Asia and South America, the elites and the ruling class are less likely to invest the national wealth in productive enterprises and create jobs but instead uses this wealth to pursue their respective plea for power and control (Arezki and Nabli, 2012; Bhattacharyya and Collier, 2014). This study believed that in some cases, the elites purposely employed the model of "rent seizing" through deliberately creating newer regulations to dismantled the societal checks to grant their family and friends easy access to national revenues and control of power. Moreover, studies by Bulte et al. (2005) and De Rosa and lootty (2012) confirmed this claim by both agreeing that the elites focuses on badly dispossess institutional development and consequently promote corruption through rent-seizing and rent-seeking.

\section{Prevalence of Corruption and Despicable Institutional Quality}

Numerous studies have demonstrated beyond reasonable doubt that resource rents are thought to bring not only conflicts but also corruption, and also further reduce demand on institutional quality (Hodler, 2006; limi, 2007). Hence, this claim was countered by a prominent study by Brunnschweiler and Bulte (2008) which argued that institutions do not play any significant contribution to the character of resource curse effects. However, more recent study by Arezki and Brückner (2011) affirmed earlier studies of Atkinson and Hamilton (2003), Hodler (2006) and limi (2007) which proved resource rents have corrosive effects on the quality of a country's institutions as well as its' economic prosperity. Even though the study by Arezki and Brückner (2011) only examined the effects of oil rent on corruption and state stability for a panel of 31 oil-exporting countries between 1992 and 2005, the study uncovered that major oil producing nations significantly increases a "Political Risk Services" sourced corruption scores. Bhattacharyya and Hodler (2010) also argued that natural resources only induce corruption in countries with long-term nondemocratic regimes. Another study by Arezki and Galyfason (2011) conducted by a panel of 29 sub-Saharan countries agreed with concept of resource curse through distinction of democratic system. This study like many other studies expresses a contrary view to the above perspective through downplaying these acts as a go-between the role of institutions in resource curse propositions. Hence, it is paramount to acknowledged that various studies have established that it is the quality of institutions that decides whether resource rents can lead to resource curse or blessing state of affairs (Mehlum et al., 2006; Beck, 2011; Sarmidi et al., 2014).

\section{Oppressive Democratic Regimes}

For the past three decades, natural resources rent and revenues have rendered most resource rich nations (especially the oil-rich economies) more exposed to dictatorial system (Apergis and Payne, 2014). This study found that various studies have repeatedly demonstrated that a country with resorted collection of large revenues of natural resource rents usually tend to be less likely dependent on levying taxes on citizens, as a result, the citizens felt redundant and ignored (Bevan et al., 1999; Barma et al., 2012; Apergis and Payne, 2014). Moreover, it is also discovered that some studies have proven that these resource rich countries usually resorted to keeping resources rents and revenues secret where the citizens do not have clear picture of regime spending acquaintances (Arezki and Gylfason, 2011; Barma et al., 2012; Apergis et al., 2014). Two examples of resource rich countries best and worst performance are; the Botswana is democratically stable while Congo is an example of the worst. Though, this study realized that the tendency of sliding toward authoritarianism can be mitigated by increasing transparency of resource rents and revenues through strengthening the links between the government and their respective citizens; notably countries such as Angola, Syria, Algeria, Venezuela and Saudi Arabia as great examples. But, the majority of non-resource-rich nations that relied on citizens' 
taxation are more responsive to their citizens' welfare and also more likely to prosper under democratic regimes, for instance, India and Malaysia.

\section{Recurrent Violent Conflict and Uprising}

It is commonly anticipated that natural resources often incite internal conflict through quest for gaining common control of the resource rents by different relevant groups (Ross, 2007). However, this study found that since 1990s, most oil-producing nations were mostly anticipated to be having twice likelihood of civil war and unrest as compared to the non-oil nations (Ross, 2007; Arezki and Nabli, 2012). Moreover, an examples of this scenario can be seen in Nigeria's case of the Niger-Delta militants and Republic Biafra agitation by Igbo ethnic group of the South Eastern part, other examples are the case of Democratic Republic of Congo, Angola, Iraq and Libya (Ross, 2007; Humphreys et al., 2007; Arezki and Nabli, 2012; Apergis et al., 2014). However, this study further discovered that some key studies linked the recent violent conflicts and uprising in most resource rich countries to a political thought known as petro-aggression. This concept is defined as a tendency of oil-rich nations be instigated or targeted by international conflict; for instance, this scenario is the case of Iraq invasion of Iran and Kuwait (Karl, 2005; Humphreys et al., 2007; Boyce and Herbert, 2011; James, 2015).

\section{Patriarchy and Gender Challenges}

It is evidently clear that most resource rich nations have not been favoring women as reported in various studies among the oil rich countries (Humphreys et al., 2007; Ross, 2012; Bauer and Quiroz, 2013).Moreover, this study understood that most of oil-rich nations usually have lesser women in the workforce and undersized representation in the public enterprises as compared to countries without natural resources, therefore, most of the industries (explicitly the export-oriented manufacturing industries) are usually easier for women to enter, and hence they are less likely to succeed. According to some prominent studies by Sachs (2007) and Ross (2012), the life of a woman in natural resource-rich countries is threatened by adverse diseases such as HIV and AIDS, early pregnancy, higher school dropout as compared to their male counterparts, etc. Moreover, this study further affirmed the believed that the influx of men into resource-rich region to be associated with increasing marginalization of women in most of industries and agencies (Ross, 2012).

\section{Prevalence of Environmental shared Challenges}

In most of the resource-rich countries, the main points of extracting key precious resources mostly create numerous challenges that have adverse negative impacts on immediate user-groups and the environment (Apergis et al., 2014). This study is in agreement with Arezki and Brückner (2011) study that reported the sharing of common natural resources such as land and water around key natural resource points are believed to be having potent capabilities of becoming the hotspots of violent conflicts among key competing user-groups competing for access (Arezki and Brückner, 2011; Hassan et al., 2018). Moreover, the study further believed that environmental shared challenges aggravates conflicts between the resource extracting firm and relative communities through issues of compensations for damages caused to the communities' sources of livelihood. The resource extraction sites usually attract hefty immigration of people, even when additional employment is not necessarily available. Moreover, this setting of affairs eventually causes stress on socioeconomic and infrastructural facilities, and hence, a series of compounded environmental issues such as pollution (water and land), massive use of water, seismic disturbances, gas flaring, several political and economic problems possess predisposition of violation of human rights and abuse of power (Badeeb et al., 2016).

\section{Lessons from Nigeria}

Been an intrinsic problem associated with countries that are endowed with natural resource, resource curse was believed to be the reason for Nigeria's disastrous development experience. Since independence, Nigeria was perceived to be lagging behind in most of the conceivable metrics associated with both economic as well as political 
mechanisms. For instance, some of the economic mechanisms are the reason for the country retarded PPP terms; per capita GDP in 1970 s was about $\$ 1,113$ is still about $\$$ 2,084 as of 2000 (Adedipe, 2004). Interestingly, the latter automatically ranked Nigeria among the 15 poorest nations in the world, and have depicted the share of poor people within the country's population from about $\$ 19,000,000$ (1970) to about $\$ 90,000,000$ (2000) (Adedipe, 2004; Ajakaiye and Fakiyesi, 2009). This country has experience growth rate volatility that can be categorized worse than average country, however, the growth rate was found to be more than most oil producing countries.

Nigeria in relation to other countries (oil producing countries inclusive), the country's economy is considerably volatile as reflected by the country's standard deviation and coefficient of variation of growth rate (Ajakaiye and Fakiyesi, 2009). The discovery oil in Nigeria is the beginning of new dawn that have replenishes the country with cumulative oil rent of about $\$ 350,000,000,000$ for the period of only 35 years (Ajakaiye and Fakiyesi, 2009). However, this revenue adds only little or no value because the Nigeria's oil revenue per capita was about $\$ 325$ with per capita GDP of about $\$ 245$, notably, the country oil revenue of 1965 is about $\$ 33$ per capita with almost the same per capita GDP (Adedipe, 2004; Ajakaiye and Fakiyesi, 2009). Even though oil rents and revenues as a share of GDP declined in the country, this is as a result of the rapid expansion of GDP than growth in both oil and the real appreciation of the currency, yet US dollar value of oil revenues certainly increases globally, but the dollar value of Nigerian GDP grows even at faster rate (Adedipe, 2004).

In 2018, the world oil demand is reviewed downward at $1.54 \mathrm{mb} / \mathrm{d}$ growth to average $98.79 \mathrm{mb} / \mathrm{d}$, hence, the global oil consumption in 2019 is believed to be slightly lower than projected rate. The forecasted consumption rate in Organization for Economic Cooperation and Development (OECD) was believed to have further dropped largely because of the decrease in demands in most part of Europe and Asia. Historically, Nigeria's oil sector is believed to be facing diverse problems ranging from low production capacity of the country's refineries, fuel importation and smuggling, corruption, pipeline vandalisms to kidnapping of oil workers (Adubi and Okunmadewa, 1999). However, during the last recent decade, Nigeria has significantly made progresses towards effectively managing some its economic and fiscal oil rents. But the country still needs to address some key political mechanisms like the institutional weaknesses. Though, international experience in oil dependent countries suggests that countercyclical fiscal policy is a key to conquering the "oil curse" of periodic instability and slow development. In this regard, Nigeria made a giant step forward during 2004 to 2009 through the establishment of the Excess Crude Account (ECA) fiscal reserve that successfully insulated the country from the sharp swings in oil prices during this period (Adebile and Amusan, 2011).

But the year 2010 have revealed the remaining weaknesses in the institutional framework for macroeconomic management. Hence, an instance of macroeconomic trends in management during $2011 / 2012$ has been quite positive, and under this fiscal expansion; naira came under pressure and investor sentiment toward Nigeria became more cautious. Despite its customary economic volatility, the COVID-19 pandemic has severely shattered the Nigeria's economy. This pandemic has led to shock reduction of global oil demand which were associated with diverse lockdown imposed around the world as a preventive measure of containing the spread of the virus. Nonetheless, in the absence of an oil price shock, Nigeria's short term macroeconomic outlook looks generally strong. The foreign inflows and balance of payments surplus should continue at the existing exchange rate, however, the continuing trend of slow output growth in the country's oil sector and budgetary circumstances must remained tight in addition to being in line with real state of affairs. Nevertheless, this study believed that both Federal and State Governments can reimburse the falling oil rents and revenues relative to the size of the economy through the development of the domestic tax system and internally generated revenue. 


\section{Conclusion}

In conclusion, this study discovered that it is evidently clear that quite few resource rich nations have been doing well in terms of human, economic as well as infrastructural development. However, most of these resource rich countries are found to be performing poorly on almost all aspects of human, economic and infrastructural developments (Sachs and Warner, 1997; limi, 2007; Adebile and Amusan, 2011; Ross, 2012; Bauer and Quiroz, 2013; Badeeb et al., 2016). In fact, the past decades have seen a raft of international initiatives designed to combat corruption and improve governance in resource rich nations; for instance, the Asia-Pacific anti-corruption strategy developed by fourteen countries in these regions. Though, a recent consensus is emerging on political variables on nexus between the natural resource wealth and development outcomes, however, the overcoming of resource curse in modern universal arena required a comprehensive indulgence of varieties of social feasibility issues. It was further understood that a number of studies are asking the wrong questions; for example, asking why natural resource wealth has fostered various political ideologies which in turn stagnated regional growths and developments? Moreover, others also tend to be asking for the sociopolitical factors that enabled resource rich countries to efficiently utilize their respective resources rent efficiently besides the promotion of regional development. Lastly, with current scenario, this study affirmed the essential need for more studies regarding the effects of resource curse at country level, since the scenario is closely affiliated with the decision of relevant political elites and ruling class. This study affirmed the need for an inclusive user-group participatory planning and budgeting that can strengthen the inter-relationship between government agencies and citizens in managing of regional natural resources rents and revenues.

\section{References}

1. Adedipe, B. (2004). The Impact of Oil on Nigeria's Policy formulation. Paper presented at a conference on Nigeria: Maximising Pro-poor growth... organized by overseas Development Institute in conjunction with Nigeria Economic Submit Group, June 16th - 17th. pp2.

2. Adebile O. A, Amusan A. S (2011). "The Non-Oil Sector and the Nigeria Economy a Case Study of Cocoa Export Since 1960" International Journal of Asian Social Science, Vol.1, No.5, pp.142151.

3. Adubi, A. A. and Okunmadewa, F. Y. (1999). „Price, Exchange Rate Volatility and Nigeria's Agricultural Trade Flows: A Dynamic Analysis", Research Paper 87, African Economic Research Consortium, Nairobi, Kenya.

4. Ajakaiye, O. and Fakiyesi, T. (2009). Global Financial Crisis Discussion Series Paper 8: Nigeria, Overseas Development Institute 111 Westminster Bridge Road, London SE1 7JD pp 8-9.

5. Andersen, J. and Aslaksen, S. (2013). Oil and Political Survival. Journal of Development Economics. Vol. 100 (1); pp. 89-106.

6. Arezki, M. R and Nabli, M. M. K. (2012). Natural resources, volatility, and inclusive growth: Perspectives from the Middle East and North Africa (No. 12-111). International Monetary Fund. WP/12/111.

7. Arezki, R. and Brückner, M. (2011). Oil rents, corruption, and state stability: Evidence from panel data regressions. European Economic Review. Vol. 55 (7); pp. 955-963.

8. Arezki, R. and Gylfason, T. 2011. Resource rents, democracy and corruption: Evidence from Sub-Saharan Africa (No. 3575). CESifo working paper: Resource and Environment Economics.

9. Apergis, N. and Payne, J. E. (2014). The oil curse, institutional quality, and growth in MENA countries: Evidence from time-varying co-integration. Energy Economics. Vol. 46; pp. 1-9.

10. Auty, R. M. 2007. Natural resources, capital accumulation and the resource curse. Ecological Economics. Vol. 61 (4); pp. 627-634.

11. Auty, R M. (1993). Sustaining development in mineral economies: the resource curse thesis. Routledge, London.

12. Atkinson, G. and Hamilton, K. (2003). Savings, growth and the resource curse hypothesis. World Development. Vol. 31 (11); pp. 1793-1807.

13. Apergis, N. El-Montasser, G. Sekyere, E. Ajmi, A. N. and Gupta, R. (2014). Dutch disease effect of oil rents on agriculture value added in Middle East and North African (MENA) countries. Energy Economics. Vol. 45; pp. 485-490.

14. Barma, N. Kaiser, K. Le, T. M. and Viñuela, L. (2012). Rents to Riches. The Political Economy of Natural Resource Led Development. The World Bank. 
15. Badeeb, R. Lean, H. H. and Clark, J. (2016). The Evolution of the Natural Resource Curse. Thesis: A Critical Literature Survey. Department of Economics and Finance, University of Canterbury Christchurch, New Zealand. Working Paper No. 5/2016. 2016.

16. Bauer, A. and Quiroz, J. C. (2013). Resource Governance in the Handbook of Global Energy Policy (ed. Andreas Goldthau, Wiley-Blackwell, 2013).

17. Bhattacharyya, S. and Hodler, R. (2010). Natural Resources, Democracy and Corruption. European Economic Review. Vol. 54 (4); pp. 608-621.

18. Bhattacharyya, S. and Hodler, R. (2014). Do natural resource revenues hinder financial development? The role of political institutions. World Development. Vol. 57; pp. 101-113.

19. Beck, T. And Leaven, L. (2006). Resolution of failed banks and deposit insurers: cross-country evidence (English). Policy, Research Working Paper; no. WPS 3920. Washington, DC: World Bank.

20. Bevan, D. Collier, P. and Gunning, J. W. (1999). The Political Economy of Poverty, Equity, and Growth: Nigeria and Indonesia. Oxford and New York: Oxford University Press.

21. Blanco, L. and Grier, R. (2012). Natural resource dependence and the accumulation of physical and human capital in Latin America. Resources Policy. Vol. 37 (3), pp. 281-295.

22. Boyce, J. R. and Herbert E. J. C. (2011). Is a negative correlation between resource abundance and growth sufficient evidence that there is a "resource curse"? Resources Policy. Vol. 36 (1); pp. 1-13.

23. Boschini, A. Pettersson, J. and Roine, J. (2013). The Resource Curse and its Potential Reversal. World Development. Vol. 43; pp. 19-41.

24. Brunnschweiler, C. N. and Bulte, E. H. (2008). The resource curse revisited and revised: A tale of paradoxes and red herrings. Journal of Environmental Economics and Management. Vol. 55 (3); pp. 248-264.

25. Brunnschweiler, C. N. (2008). Cursing the blessings? Natural resource abundance, institutions, and economic growth. World Development. Vol. 36 (3); pp. 399-419.

26. Bulte, E. H. Damania, R. and Deacon, R. T. (2005). Resource Intensity, Institutions and Development. World Development. Vol. 33; pp. 1029-1044.Corden, W. M. and Neary, P. J. 1982. Booming sector and deindustrialization in a small open economy. Economic Journal. Vol. 92; pp. 825-848.

27. Corden W. M. (1984). Booming sector and Dutch disease economics. Oxford Economic Papers. Vol. 36; pp. 359-380

28. Collier, P. and Hoeffler, A. (2005). Resource rents, governance, and conflict. Journal of Conflict Resolution. Vol. 49 (4); pp. 625-633.

29. Davis, G. and Tilton, J. E. 2005. The resource curse. Natural Resource Forum. Vol. 29; pp. 2342.

30. Deacon, R. T. and Rode, A. (2012). Rent seeking and the resource curse. UCSB Department of Economics, University of California, USA.

31. De Rosa, D. and lootty, M. (2012). Are natural resources cursed? an investigation of the dynamic effects of resource dependence on institutional quality. World Bank. Policy Research Working Paper 6151.

32. Egorov, G. Guriev, S. M. and Sonin, K. (2009). Why resource Poor Dictators Allow Freer Media: A Theory and Evidence from Panel Data. American Political Science Review. Vol. 103 (4); pp. 645-668.

33. Frankel, J. A. (2010). The natural resource curse: a survey. National Bureau of Economic Research. (No. w15836).

34. Gelb, A. (1988). Oil Windfalls: Blessing or Curse? Growth in Resource-rich Economies. World Development. Vol. 72; pp. 109-126.

35. Gylfason, T. \& Zoega, G. (2006). Natural resources and economic growth: the role of investment. World Economy. Vol. 29; pp. 1091-1115.

36. Gylfason, T. Herbertsson, T. T. and Zoega, G. (1999). A mixed blessing. Macroeconomic dynamics. Vol. 3 (02); pp. 204-225.

37. Gylfason, T. (2001). Natural resources, education, and economic development. European Economic Review. Vol. 45 (4); pp. 847-859.

38. Hammond, J. L. (2011). The resource curse and oil revenues in Angola and Venezuela. Science and Society. Vol. 75 (3); pp. 348-378.

39. Hassan, Y. Hassan, A. A. and Hussain, N. (2018). Occupational Politics Myths and Realities in Nigeria: A Case of Farmers-Pastoralists Conflicts. International Journal of Technical Research and Science, 3(10), 329-337.

40. Hodler, R. (2006). The curse of natural resources in fractionalized countries. European Economic Review. Vol. 50 (6); pp. 1367-1386. 
41. Humphreys, M. Sachs, J. and Stiglitz, J. E. (Eds.). 2007. Escaping the resource curse (pp. 1113). New York: Columbia University Press.

42. limi, A. (2007). Escaping from the resource curse: Evidence from Botswana and the rest of the World. IMF Staff Papers. Vol. 54; pp. 663-699.

43. Ismail, K. (2010). The Structural Manifestation of the Dutch Disease': The Case of Oil Exporting Countries. IMF Working Paper, WP/10/103.

44. Isham, J. L. Pritchett, M. W. and Busby, G. (2005). The Varieties of Resource Experience: Natural Resource Export Structures and the Political Economy of Economic Growth. World Bank Economic Review. Vol. 19; pp. 141-174.

45. James, A. (2015). The resource curse: A statistical mirage? Journal of Development Economics. Vol. 114; pp. 55-63.

46. Karl, T. L. (2005). Understanding the resource curse, in S. Tsalik and A. Schiffrin (eds) Covering Oil: A Reporter's Guide to Energy and Development, New York: Open Society Institute. pp. 2137.

47. Lam, R. and Wantchekon, L. (2003). Political Dutch Disease. Working Paper, Northwestern University.

48. Leite, C. and Weidmann, J. (1999). Does Mother Nature Corrupt? Natural Resources, Corruption and Economic Growth. Washington, DC: International Monetary Fund, IMF Working Paper WP/99/85.

49. Loayza, N. Mier, Y. Teran, A. and Rigolini, J. (2013). Poverty, inequality, and the local Natural resource curse (No. 7226). World Bank, Policy Research Working paper (6366).

50. Mehrara, M. (2009). Reconsidering the resource curse in oil-exporting countries. Energy Policy. Vol. 37 (3); pp. 1165-1169.

51. Mehlum, H. Moene, K. and Torvik, K. (2006). Institution and the resource Curse. The Economic Journal. Vol. 116; pp. 1-20.

52. Raj M. D. Olofsgård, A. and Yousef, T. (2009). The Logic of Authoritarian Bargains. Economics and Politics. Vol. 21 (1); pp. 93-125.

53. Ross, M. (2007). How Mineral-Rich States Can Reduce Inequality, Chapter 9 in Escaping the Resource Curse, edited by M. Humphreys, J. Sachs and J. Stiglitz (Columbia University Press: NY). Pp. 236-255.

54. Ross, M. (2012). The Oil Curse. (Princeton UP)

55. Sachs, J. D. and Warner, A. M. 2001. The curse of natural resources. European economic review. Vol. 45 (4); pp. 827-838.

56. Sachs, J. D. (2007). How to handle the macroeconomics of oil wealth. Chapter 7 in Escaping the Resource Curse, edited by M. Humphreys, J. Sachs and J. Stiglitz (Columbia University Press: NY). Pp. 173-193.

57. Sachs, J. D. and Warner, A. M. (1997). Natural resource abundance and economic growth. Center for International Development and Harvard Institute for International Development.

58. Sarmidi, T. Law, S.H. and Jafari, Y. (2014). Resource curse: new evidence on the role of institutions. International Economic Journal. Vol. 28 (1); pp. 191-206.

59. Sala-i-Martin, X. and Subramanian, A. (2003). Addressing the natural resource curse: An illustration from Nigeria. National Bureau of Economic Research (NBER). Working Paper 9804.

60. Shao, S. and Yang, L. (2014). Natural resource dependence, human capital accumulation, and economic growth: A combined explanation for the resource curse and the resource blessing. Energy Policy. Vol. 74; pp. 632-642.

61. Singer, H. W. (1950). The distribution of gains between investing and borrowing countries. American Economic Review. Vol. 15; pp. 473-485.

62. Stevens, P. and Dietsche, E. (2008). Resource curse: An analysis of causes, experiences and possible ways forward. Energy Policy. Vol. 36 (1); pp. 56-65.

63. Stevens, P., and Dietsche, E. (2008). Resource curse: An analysis of causes, experiences and possible ways forward. Energy Policy. Vol. 36 (1); pp. 56-65.

64. Vincente, P. C. 2010. Does Oil Corrupt? Evidence from Natural Experiment in Africa. Journal of Development Economics. Vol. 92 (1); pp. 28-38.

65. Van der Ploeg, F. and Poelhekke, S. (2009). Volatility and the natural resource curse. Oxford economic papers. Vol. 61 (4); pp. 727-760. 